\title{
Is Environmental Performance Valued by Investors? The Case of Indonesian Listed Companies
}

\author{
Felisha Felisha ${ }^{1}$, Hilda Rossieta $^{1 *}$ \\ ${ }^{1}$ Faculty of Economics and Business, Universitas Indonesia, Depok 16424, Indonesia \\ *hilda.rosieta@ui.ac.id
}

\begin{abstract}
This study aimed to investigate whether environmental performance is valuable to investors. Lower environmental performance is associated with higher litigation and sustainability risk; therefore, investors will ask for a higher return premium for low environmental performance, and vice versa. This study used the results of the Companies'Performance-Rating Assessment Program (Program Penilaian Peringkat Kinerja Perusahaan) (PROPER), conducted by the Indonesian Environmental Ministry, as a proxy for environmental performance. The empirical results show that environmental performance is positively associated with the cost of debt. This research found no association between environmental performance and the cost of equity.
\end{abstract}

Keywords: Environmental Performance; Cost of Debt; Cost of Equity; Indonesian Listed Companies.

\section{INTRODUCTION}

Companies with bad environmental performance are viewed as risky investments ${ }^{1}$. Those companies have a higher exposure to litigation risk than companies with good environmental performance. The higher risk exposure motivates investors to demand higher returns from their investment in those companies with bad environmental performance.

Previous research on environmental performance, economic performance, and environmental disclosures ${ }^{2-6}$ focus on the effect of environmental performance on financial performance from the investors' perspective, which are usually measured using return on equity and return on assets. However, it is unclear how investors value the performance.

In contrast, this research argues that environmental performance is valued by investors through the market mechanism for the cost of funds. This research looks at the debt holders' and shareholders' perspective in terms of the cost of debt and the cost of equity, respectively.

Studies about the effect of environmental performance on the cost of debt and cost of equity, have been mostly done for developed countries such as Australia ${ }^{7}$, North America ${ }^{8}$, Europe $^{8}$, and the USA ${ }^{9}$. To measure environmental performance, these previous studies used a variety of approaches relevant to the study's context. Although researchers have started to express interest in environmental-performance issues, and yet most of the measures used refer to the research conducted in developed countries ${ }^{10}$.

This study tries to address the contextual limitations of the previous studies by using environmental performance measures specific to the Indonesian context. Accordingly, this study uses the rating provided by Indonesian Environmental Ministry through the program named the Companies'-Performance-Rating Assessment Program (Program Penilaian Peringkat Kinerja Perusahaan) (PROPER).

The research is presented in several sections, as follows. Section 2 explains the conceptual foundation and hypothesis development. Section 3 describes the research method used to test the hypotheses. The empirical test results and interpretation are presented in Section 4. Finally, this research is concluded in Section 5.

\section{LITERATURE REVIEW AND HYPOTHESIS DEVELOPMENT}

\section{Legitimacy Theory and Environmental Performance}

Legitimacy theory explains the social contract between the social system and companies ${ }^{11}$. This social contract encourages companies to act according to the norms and values accepted in society. To be able to sustain themselves, companies should operate according to the demands and expectations of society. Legitimacy is a strategic factor that enables companies to operate in the long run.

\section{Stakeholders Theory and Environmental Performance}

Stakeholders' focus on the environment ${ }^{12}$, which increases the demand for companies to be more environmentally responsible in their operations ${ }^{13}$. Nowadays, society considers environmental problems to be companies' responsibilities ${ }^{12}$. The escalating stakeholders' concerns with respect to the environment have motivated companies to deliver a high level of environmental performance. 
In an Indonesian context, one of the assessments of environmental performance is conducted under PROPER, by the State Ministry of the Environment. According to PROPER, performance is categorized into five ranks, each coded by a specific color, which are ranked from the highest to the lowest as follows: (i) gold; (ii) green; (iii) blue; (iv) red; (v) black. Based on the latest regulation of the State Ministry of the Environment, which is No.3 article 5/2014, the assessment is focused on the following: (i) compliance with environmental licensing; (ii) water-pollution control; (iii) air-pollution control; (iv) management of dangerous and poisonous waste; (v) environmental-damage control, specifically for the mining industry. Companies with gold, green, and blue ratings are those that have already complied with the regulations, while companies with red and black ratings are those that have not yet fully complied with the regulations.

\section{Agency Theory and Environmental Performance}

Agency theory explains the conflict of interest between the principal (shareholders) and the agent (managers) $)^{14}$. Shareholders, especially long-term investors, expect companies to invest adequately in the environment, so that companies become more stable and can sustain themselves in the long run. However, investing in the environment is often expensive, and yet the return is mostly uncertain. On the other hand, managers, as agents, are required to provide optimal returns for shareholders, as the owners, and must maintain an adequate cash flow to pay interest as well as the principal to the debt holders. In addition, as an agent, managers usually have a limited period of assignment. Investing in the environment may reduce company's profit in the short term. Therefore, managers do not have strong incentives to invest in the environment. To a certain extent, managers' reluctance to engage in environmental investment is consistent with the motivation of short-term-equity investors, who seek capital gains from buying and selling activities in the capital market. Accordingly, companies' environmental performance is very likely to be less appreciated and valued by short-term-equity investors.

\section{The Theory of Finance as the Foundation for Investment Decisions}

The theory of finance explains the concept of a trade-off between risk and return ${ }^{15}$. Risk is defined as the real chance of gaining a return from an investment. The behavior of both equity investors and debt investors is most likely to be affected by the company's risk. A significant positive association was found between risk and return ${ }^{16}$. This means that if a company's risk is high, then the investors will ask for a higher return to compensate for the high risk.

\section{Environmental Performance and the Interest of Debt-investor}

Companies with better environmental risk management represent a better strategy to minimize risk. Lower risk can be reflected in a lower cost of debt and lower cost of equity. The risk of debt covenant increases in the opposite direction to companies' environmental performance.

Legitimacy theory and stakeholder theory ${ }^{11}$ suggest that companies with bad environmental performance will be more likely to experience litigation risk, which will also reduce companies' ability to return the borrowings. Accordingly, a debt-investor tends to charge a higher cost of debt to companies with low environmental performance.

However, environmental investment is often costly and may reduce companies' capability to pay interest as well as the principal of the debt. Accordingly, debt holders may perceive the reduced capability as a risky investment; therefore, they are most likely to demand a higher return ${ }^{16}$. In this case, companies with high environmental performance could be associated with high environmental investment, which are considered to be riskier, and hence are required to pay a higher cost of debt.

Based on the arguments regarding environmental performance and the cost of debt, the first hypothesis suggested is as follows:

H1: High environmental performance is more likely to be associated with high cost of debt.

\section{The Association between Environmental Performance and Shareholders' Interest}

A study ${ }^{7}$ argue that post cost-benefit trade-off, (i.e., environmental investments are expected to be compensated in the future) is one important considerations for investors' decisions. This is consistent with stakeholder theory, in that better environmental performance will attract investors ${ }^{2}$; hence, the lower the cost of equity.

On the other hand, costly environmental investments might reduce companies' profitability in the short run, but the return in the long run is unclear. Accordingly, equity investors might perceive that environmental investment is riskier; therefore, companies with good environmental performance would be demanded to pay a higher cost of equity.

H2: High environmental performance is more likely to be associated with high cost of equity. 


\section{RESEARCH METHOD}

This research used a sample of Indonesian listed companies from the period of 2011 to 2015. The PROPER rating categories (using the aforementioned five-colour system to identify the degree of regulatory compliance) is used as a proxy for environmental performance. In general, compliant companies are indicated by the gold, green, and blue colors, while red and black indicate non-compliant companies.

The first hypothesis, H1, is tested by Model 1, while H2 is tested by Model 2, as follows:

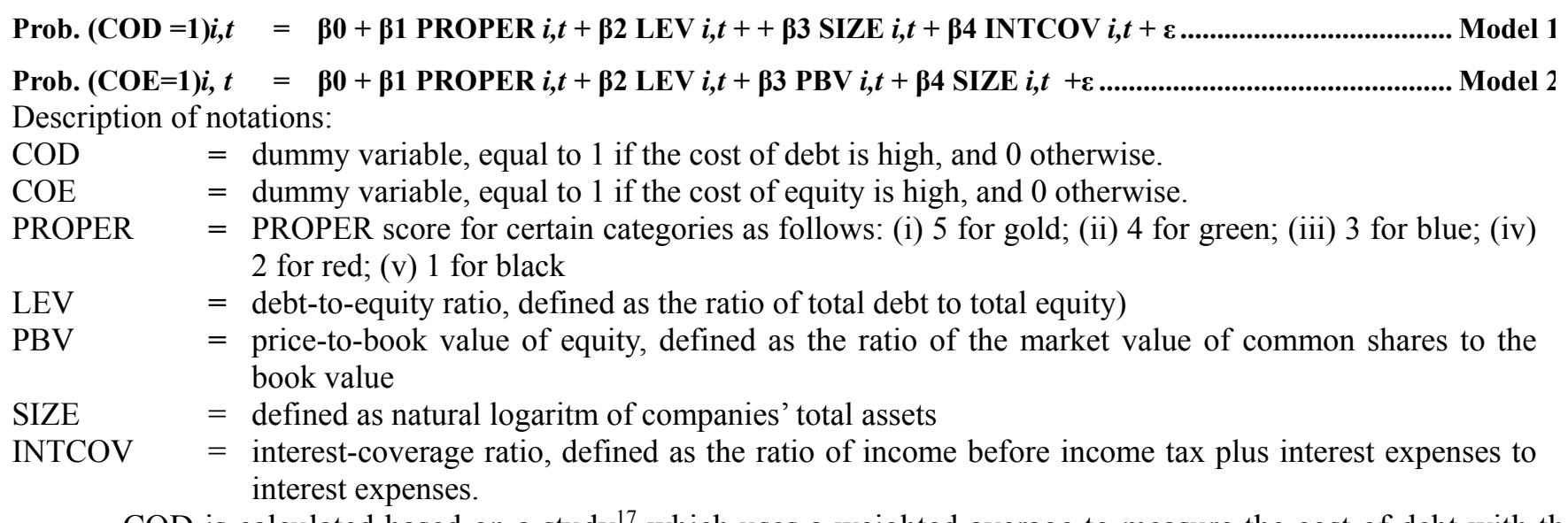
following formula:

Cost of debt $=$ interest expense $/$ average interest-bearing debt

Based on capital-asset-pricing-model (CAPM) theory, COE is calculated in a way that is consistent with the research done by prior researches ${ }^{10,18,19}$, and is calculated with the following formula:

Cost of equity $=\mathrm{Rf}+\beta(\mathrm{Rm}-\mathrm{Rf})$

Where Rf denotes the risk-free rate measured using the State Bank of Indonesia's (SBI's) rate in one year, $\beta$ is the market beta measured using the regression between a share's return and market return, and market risk premium is the additional return expected by investors for investing in a risky security.

\section{RESULTS AND DISCUSSION}

This research identifies 157 firm-year observations, which are qualified as the sample. The descriptive statistics of the sample suggest that the skewness statistic for some variables in the equations (i.e., COD, PBV, and IntCov) is quite skewed (i.e., $\geq \pm 2$ ). Accordingly, the mode statistic for COE is $8.9 \%$ and for COD is $10.75 \%$. This result is in line with previous study ${ }^{20}$, who state that most of Indonesia's companies are more likely to be funded by loans rather than by shares.

With regards to the category variable, the frequency distribution shows that the majority of the sample companies are pursuing environmental performance just to comply with the minimal requirements stated by the regulations (i.e., $64 \%$ of the sample are categorized as blue-rated companies). In addition, the majority of the sample companies are categorized as having low COD (i.e., 73.89\%) and high COE (i.e., $80.89 \%$ ). The results of the empirical tests are presented in Table 1.

Table 1 suggests that PROPER only affects COD in Model 1, but has no effect on the COE in Model 2. Accordingly, each unit increase in the PROPER score would increase the likelihood of the companies having a high COD by around $61.9 \%$. This is consistent with $\mathrm{H} 1$, the results suggest that high environmental performance is more likely to be associated with high COD.

For robustness, the effects of PROPER on COD and COE are tested using covariate and univariate statistics. Consistent with the findings of the binary logistic test, PROPER is positively correlated with COD only (coeff. of correlation $=0.221$, significant at $\mathrm{p} \leq 1 \%$ ), but has no correlation with COE. In addition, the univariate test of companies with high COD but low COD suggests that these two groups have different PROPER scores, where the high group has a higher PROPER score (i.e., 3.244) compared to the low group (i.e., 2.888, significant at $\mathrm{p} \leq 1 \%$ ). On the contrary, the PROPER scores of high and low COE groups are not significantly different. The univariate test results are consistent with the results of means comparisons between the high and low group of COD and COE. Accordingly, the high and low COD groups have significantly different means at $\mathrm{p} \leq 5 \%$, while the differences in means of the high and low COE groups are statistically insignificant.

The finding suggests that Indonesian debt investors ask for a premium for a high rating of PROPER environmental performance. Environmental investment is perceived as costly, and yet the associated impact of the investment is unclear. Consequently, costly environmental investment will impair companies' cash flow and ability to pay the principal of a debt and its interest. In other words, companies with high environmental performance are perceived as riskier compared to others; therefore, debt investors demand a higher return ${ }^{16}$. 
With regards to COE, the empirical evidence shows no association with environmental performance. Compared to debt investors, equity investors have more flexibility to enter to or exit from the stock market, and formulate the portfolio of investments that match their risk appetite. Consequently, equity investors do not perceive environmental performance as important; hence, they do not relate the performance to the discount or premium demanded.

Table.1. Empirical Results for the Binary Logistics Statistical Tests of Model 1 (COD) and Model 2 (COE)

\begin{tabular}{|c|c|c|c|c|}
\hline \multirow[t]{2}{*}{ Variable } & \multicolumn{2}{|c|}{ Model 1 - COD } & \multicolumn{2}{|c|}{ Model - COE } \\
\hline & B & $\begin{array}{c}\text { Exp } \\
\text { (B) }\end{array}$ & B & $\begin{array}{c}\text { Exp } \\
\text { (B) }\end{array}$ \\
\hline Constant & $-14.744 \quad * * *$ & $\overline{0}$ & $-5.217 *$ & 0.005 \\
\hline PROPER & $0.482 *$ & 1.619 & -0.27 & 0.764 \\
\hline$\overline{\mathrm{LEV}}$ & -0.017 & 0.983 & -0.008 & 0.992 \\
\hline PTB & $0.322 \quad * * *$ & 1.38 & -0.052 & 0.949 \\
\hline SIZE & $0.542 \quad * * *$ & 1.719 & $0.349 \quad * * *$ & 1.418 \\
\hline INTCOV & $-0.029 \quad * * *$ & 0.972 & & \\
\hline $\begin{array}{l}\text { Omnibus Tests } \\
\text { of Model } \\
\text { Coefficients }\end{array}$ & \multicolumn{2}{|l|}{$0.00 * * *$} & \multicolumn{2}{|l|}{0.136} \\
\hline $\begin{array}{l}\text { Nagelkerke R } \\
\text { Square }\end{array}$ & \multicolumn{2}{|l|}{$30.20 \%$} & \multicolumn{2}{|l|}{$7 \%$} \\
\hline $\begin{array}{l}\text { Hosmer and } \\
\text { Lemeshow Test }\end{array}$ & \multicolumn{2}{|l|}{$52.10 \%$} & \multicolumn{2}{|l|}{$61.80 \%$} \\
\hline $\begin{array}{l}\text { Overall } \\
\text { Percentage } \\
\text { Correct for the } \\
\text { model }\end{array}$ & \multicolumn{2}{|l|}{$77.70 \%$} & \multicolumn{2}{|l|}{$80.90 \%$} \\
\hline & & $*$; & $\%$ & \\
\hline
\end{tabular}

\section{CONCLUSION}

This study aimed to investigate whether environmental performance is valued by investors. The empirical results suggested that environmental performance is only appreciated by debtholders, but not by shareholders.

However, the results are contradictory to the empirical findings in developed countries, where high environmental performance is perceived as having lower environmental risk; hence, it is negatively associated with COD. One of the interpretations is that debtholders perceive a costly environmental investment to be a risky investment due to the unclear and uncertain return ${ }^{16}$; hence, they ask for a risk premium for their investment.

This study has several limitations. This research uses the PROPER rating as the measure of environmental performance, which is relevant in an Indonesian context only. Hence, the results could not be generalized to other contexts. Although the unique context could provide better insight regarding the environmental-performance issues, the associated unique incentive system is hardly discussed in this research. Therefore, future research should address the unique incentive system for environmental performance in this specific context to better understand the contextual reality.

\section{REFERENCES}

[1] T. E. Schneider. Is there a relation between the cost of debt and environmental performance? An empirical investigation of the U.S. pulp and paper industry, 1994-2005, Thesis for Doctor of Philosophy, University of Waterloo (2008).

[2] K. H. Titisari, K. Alviana. Pengaruh environmental performance terhadap economic performance. Jurnal Akuntansi dan Keuangan Indonesia, 9(1)(2012) 56-67.

[3] S. Sarumpaet. The relationship between environmental performance and financial performance of Indonesian companies. Jurnal Akuntansi \& Keuangan, 7(2)(2005) 89-98.

[4] A. Rokhmawati, M. Sathye, and S. Sathye. The effect of GHG emission, environmental performance, and social performance on financial performance of listed manufacturing firms in Indonesia. Procedia - Social and Behavioral Sciences, 211(2015) 461-470.

[5] D. Angelia and R. Suryaningsih. The effect of environmental performance and corporate social responsibility disclosure towards financial performance (Case study to manufacture, infrastructure, and service companies that listed at Indonesia Stock Exchange). Procedia - Social and Behavioral Sciences, 211(2015) 348-355.

[6] P. N. Saridewi and D. P. Koesrindartoto. The link between social, environmental to financial performances of companies in Indonesia. International Conference on Trends in Economics, Humanities, and Management, Pattaya, Thailand (2014).

[7] A. C. Ng, Z. Rezaee. Business sustainability performance and cost of equity capital. Journal of Corporate Finance, 34(2015) 128-149.

[8] Z. Y. Feng, M. L. Wang, H. W. Huang. Equity financing and social responsibility: Further international evidence. The International Journal of Accounting, 50(3)(2015) 247-280. 
[9] M. Cajias, F. Fuerst, S. Bienert. Can investing in corporate social responsibility lower a company's cost of capital?. Studies in Economics and Finance, 31(2)(2014) 202-222.

[10] Y. Rebecca. Pengaruh corporate governance index, kepemilikan keluarga, dan kepemilikan institusional terhadap biaya ekuitas dan biaya utang: Studi empiris pada perusahaan manufaktur yang terdaftar di BEI. Skripsi, Universitas Indonesia (2012).

[11] J. C. Chen, R. W. Roberts. Toward a more coherent understanding of the organization-society relationship: A theoretical consideration for social and environmental accounting research. Journal of Business Ethics, 97(4)(2010) 651-665.

[12] A. P. Setiowati. Analisis hubungan antara kinerja lingkungan dan kinerja keuangan perusahaan pertambangan peserta PROPER yang terdaftar pada Bursa Efek Indonesia periode 2003-2007. Skripsi, Universitas Indonesia (2009).

[13] M. A. Berry, D. A. Rondinelli. Proactive corporate environmental management: A new industrial revolution. Academy of Management Executive, 12(2)(1998) 38-50.

[14] M. C. Jensen, W. H. Meckling. Theory of the firm: Managerial behavior, agency costs and ownership structure. Journal of Financial Economics, 3(4)(1976) 305-360

[15] L. A. Alles. Investment risk concepts and measurement of risk in asset returns. Managerial Finance, 21(1)(1995) 15-25.

[16] E. Ghysels, P. Santa-Clara, R. Valkanov. There is a risk-return trade-off after all. Journal of Financial Economics, 76(3)(2005) 509-548.

[17] J. R. Francis, I. K. Khurana, R. Pereira. Disclosure incentives and effects on cost of capital around the world. The Accounting Review, 80(4)(2005) 1125-1162.

[18] S. A. H. Murni. Pengaruh luas ungkapan sukarela dan asimetri informasi terhadap cost of equity capital pada perusahaan publik di Indonesia. Simposium Nasional Akuntansi VI, Surabaya, Indonesia, (2003).

[19] Z. Riduan. Pengaruh tingkat pengungkapan sukarela terhadap cost of equity capital dengan likuiditas saham sebagai variabel mediasi. Skrispi, Universitas Indonesia (2010).

[20] P. Bunkanwanicha, J. Gupta, R. Rokhim. Debt and entrenchment: Evidence from Thailand and Indonesia. European Journal of Operational Research, 185(3)(2008) 1578-1595. 